\title{
Effects of an Enkephalin Analogue (DAMME) on Insulin Release from Cultured Rat Islets of Langerhans
}

\author{
R. Pierluissi, J. Pierluissi, and S. J. H. Ashcroft \\ Nufficld Department of Clinical Biochemistry, John Radcliffe Hospital, Oxford, England
}

Summary. Rat islets of Langerhans were maintained for 2 days in tissue culture. Following the culture period, the insulin secretory responses of the islets on incubation in bicarbonate medium were measured. The enkephalin analogue D-ala ${ }^{2}, \mathrm{MePhe}^{4}, \operatorname{Met}(0)$-ol (DAMME), $8.3 \times 10^{-8} \mathrm{~mol} / \mathrm{l}$, augmented insulin release stimulated by glucose ( 5 or $7 \mathrm{mmol} / \mathrm{l}$ ) by $76 \%$ and $47 \%$ respectively; increased insulin release stimulated by $\alpha$-ketoisocaproate $(7.5 \mathrm{mmol} / \mathrm{l})$ by $23 \%$; and enhanced insulin release in the presence of glibenclamide $(10 \mu \mathrm{g} / \mathrm{ml})$ plus glucose $(3.3 \mathrm{mmol} / \mathrm{l})$ by $38 \%$. Insulin release in the presence of glucose at 2 or $12 \mathrm{mmol} / \mathrm{l}$ was not affected by DAMME $\left(8.3 \times 10^{-8} \mathrm{~mol} / \mathrm{l}\right)$. The potentiatory effect of DAMME on insulin release in the presence of glucose $(5 \mathrm{mmol} / \mathrm{l})$ was blocked by naloxone $(11 \mu \mathrm{mol} / \mathrm{l})$ : naloxone alone did not affect glucose-stimulated insulin release. A high concentration $(3.3 \times$ $10^{-6} \mathrm{~mol} / \mathrm{l}$ ) of DAMME did not modify glucosestimulated insulin release. Inhibition of glucosestimulated insulin release by trifluoperazine, an inhibitor of calmodulin, was not overcome by DAMME. Insulin secretory responses were not enhanced by exposure of the islets to DAMME $\left(8.3 \times 10^{-8} \mathrm{~mol} / \mathrm{l}\right)$ during the culture period. It is concluded that insulin release from isolated islets is capable of being influenced by an opioid peptide.

Key words: Enkephalin, insulin secretion, islets of Langerhans, naloxone, islet culture, DAMME.

Studies on identical twins $[1,2,3]$ have suggested that non-insulin dependent diabctes is predominantly inherited and it has been reported to be strongly associated with chlorpropamide alcohol flushing [4]. It has been suggested that the latter may be due to sensitivity to enkephalin [5] and it has been proposed $[5,6,7]$ that enkephalin and other opioid peptides could play a role in the aetiology of non-insulin dependent diabetes. Opioid peptides have been shown to influence the secretion of several pituitary hormones [8-11] and the presence of immunoreactive enkephalin [12] and endorphin [13,14] in the pancreatic islets has been demonstrated. Studies using the perfused dog pancreas [15] and rat islets $[16,17]$ have provided evidence that opiates can influence the secretion of the endocrine pancreas. In man, however, administration of an enkaphalin analogue [18] or of the opiate antagonist naloxone [11] did not influence the serum levels of insulin or glucagon despite changes in the levels of several other hormones. In the present study we have examined the effects of the enkephalin analogue D-Ala ${ }^{2}, \mathrm{MePhe}^{4}, \mathrm{Met}(0)$-ol (DAMME) on insulin release from pancreatic islets of the rat in response to glucose, $\alpha$-ketoisocaproate and glibenclamide.

\section{Materials and Methods}

\section{Materials}

Tissue culture medium RPMI 1640 containing $11 \mathrm{mmol} / \mathrm{l}$ glucose, was obtained from Gibco (Europe), Paisley, Scotland. Collagenase (Type 1) was from Sigma London, Poole, L. K. ${ }^{125}$ I-insulin $(50 \mu \mathrm{Ci} / \mu \mathrm{g})$ was from the Radiochemical Centre, Amersham, U.K. Anti-insulin serum and foetal calf-serum were obtained from Wellcome Reagents, Beckenham, U. K. Naloxone was from Winthrop Laboratories, U. K. DAMME was a gift from Sandoz Products, Feltham, U. K. Other chemicals were from British Drug Housc, Poole, U. K.

\section{Preparation of Islets}

Islets were obtained from the pancreases of fed Wistar rats maintained on a standard laboratory diet (PRM, E. Dixon \& Sons, Ware), by a collagenase method [19]. 
Table 1. Effects of DAMME on insulin release stimulated by glucose, $\alpha$-ketoisocaproate and glibenclamide

\begin{tabular}{|c|c|c|c|c|c|c|}
\hline \multirow[t]{2}{*}{ Line } & \multicolumn{2}{|c|}{ Incubation conditions } & \multirow[b]{2}{*}{$\begin{array}{l}\text { DAMME } \\
\left(8.3 \times 10^{-8}\right. \\
\mathrm{mol} / \mathrm{l})\end{array}$} & \multirow[b]{2}{*}{$\begin{array}{l}\text { Insulin release } \\
(\mu \mathrm{L} / \text { islet } / \mathrm{h})\end{array}$} & \multirow[b]{2}{*}{ n } & \multirow[b]{2}{*}{$\mathrm{p}$} \\
\hline & $\begin{array}{l}\text { Glucose concn. } \\
(\mathrm{mmol} / \mathrm{l})\end{array}$ & Other additions & & & & \\
\hline 1 & 2 & - & - & $20 \pm 3$ & 25 & \\
\hline 2 & 2 & - & + & $28 \pm 4$ & 25 & NS vs 1 \\
\hline 3 & 5 & - & - & $51 \pm 5$ & 25 & \\
\hline 4 & 5 & - & + & $90=8$ & 25 & $\leqslant 0.001$ vs. 3 \\
\hline 5 & 7 & - & - & $159 \pm 12$ & 25 & \\
\hline 6 & 7 & - & + & $233 \pm 12$ & 25 & $\leqslant 0.001$ vs. 5 \\
\hline 7 & 12 & - & - & $215 \pm 19$ & 25 & \\
\hline 8 & 12 & - & + & $259 \pm 25$ & 25 & NS vs. 7 \\
\hline 9 & - & - & - & $18 \pm 3$ & 20 & \\
\hline 10 & - & $\alpha$-ketoisocaproate $7.5 \mathrm{mmol} / \mathrm{l}$ & - & $128 \pm 8$ & 20 & \\
\hline 11 & - & $\alpha$-ketoisocaproate $7.5 \mathrm{mmol} / \mathrm{l}$ & + & $158 \pm 10$ & 20 & $\leqslant 0.05$ vs. 10 \\
\hline 12 & 3.3 & - & - & $9 \pm 1$ & 20 & \\
\hline 13 & 3.3 & - & + & $10 \pm 2$ & 20 & NS vs. 12 \\
\hline 14 & 3.3 & glibenclamide $10 \mu \mathrm{g} / \mathrm{ml}$ & - & $94 \pm 8$ & 20 & \\
\hline 15 & 3.3 & glibenclamide $10 \mathrm{ug} / \mathrm{ml}$ & + & $130 \pm 10$ & 20 & $\leqslant 0.001$ vs. 14 \\
\hline
\end{tabular}

Rat islets were cultured for 2 days in RPMI-1640. After culture, the islets were incubated for $2 \mathrm{~h}$ in bicarbonate medium containing glucose, $\alpha$-ketoisocaproate or glibenclamide at the concentrations stated in the absence or presence of DAMME $\left(8.3 \times 10^{-8} \mathrm{~mol} / \mathrm{l}\right)$. Insulin released into the medium was determined by radioimmunoassay. Results are given as mean \pm SEM for the number of batches of islets ( $\mathrm{n}$ ) given. For each expcrimental series the data were pooled from the following numbers of islet preparations and rats: lines 1-8, 5 preparations, 20 rats; lines $9-11,4$ preparations, 6 rats; lines $12-15,4$ preparations, 8 rats

\section{Islet Culture}

Prior to mcasurements of insulin release, islets wcre maintained in culture for 2 days at $37^{\circ} \mathrm{C}$ in RP.MI 1640 containing glucose $11 \mathrm{mmol} / 1$, penicillin $(150$ units $/ \mathrm{ml})$, streptomycin $(0.5 \mathrm{mg} / \mathrm{ml})$ and calf serum $(10 \%)$ in an atmosphere of $95 \%$ humidified air: $5 \% \mathrm{CO}_{2}$. Groups of 55 islets were kept in sterile Petri dishes (Sterilin) containing $5 \mathrm{ml}$ culture medium.

\section{Insulin Release}

Following the culture period, batches of 5 islets were incubated for $2 \mathrm{~h}$ at $37^{\circ} \mathrm{C}$ in bicarbonate medium $\mathrm{pH} 7.4[20]$ containing albu$\min (2 \mathrm{mg} / \mathrm{ml})$ and other additions as stated in the text or tables. Insulin released into the medium was measured by a charcoal radioimmunoassay as previously described [21].

\section{Treatment of Results}

Results are given as mean \pm SEM for the number of batches of islets stated. The data given are the pooled results from the number of separate islet preparations indicated: the number of rats used for each series of experiments is also given. The probability of no real difference between experimental and control groups was assessed by the two-tailed Student $t$-test and by the non-parametric Mann-Whitncy U-test [22].

\section{Results}

The effects of DAMME $\left(8.3 \times 10^{-8} \mathrm{~mol} / \mathrm{l}\right)$ on insulin released in the presence of different concentrations of glucose are shown in Table 1. DAMME did not significantly affect basal insulin release in the presence of $2 \mathrm{mmol} / \mathrm{l}$ glucose nor the near-maximal rate of release seen with $12 \mathrm{mmol} / \mathrm{l}$ glucose. However at intermediate glucose concentrations ( 5 or $7 \mathrm{mmol} / \mathrm{l}$ ), DAMME significantly increased insulin release by $76 \%$ and $47 \%$ respectively. Insulin release in the presence of $5 \mathrm{mmol} / 1$ glucose was also increased $50 \%$ by $1.7 \times 10^{-8} \mathrm{~mol} / 1 \mathrm{DAMME}$ but the much higher concentration of $3.3 \times 10^{-6} \mathrm{~mol} / \mathrm{l}$ did not significantly affect insulin release (release with DAMME $3.3 \times 10^{-6} \mathrm{~mol} / \mathrm{l}$, and glucose $5 \mathrm{mmol} / 1$, was $112 \pm$ $9 \%$ of that seen with $5 \mathrm{mmol} / \mathrm{l}$ glucose alone: data for 20 batches of islets from 10 rats). The effects of DAMME on insulin release stimulated by $\alpha$ ketoisocaproate or glibenclamide are also shown in Table 1. $\alpha$-Ketoisocaproate $(7.5 \mathrm{mmol} / \mathrm{l})$ increased insulin release sevenfold: the response to $\alpha$ ketoisocaproate was significantly cnhanced by $8.3 \times$ $10^{-8} \mathrm{~mol} / 1 \mathrm{DAMME}$. In the presence of $3.3 \mathrm{mmol} / \mathrm{l}$ glucose, glibenclamide $(10 \mu \mathrm{g} / \mathrm{ml})$ increased insulin release tenfold. DAMME $\left(8.3 \times 10^{-8} \mathrm{~mol} / \mathrm{l}\right)$ further augmented the response to glibenclamide by $38 \%$ but was without effect on the release with $3.3 \mathrm{mmol} / 1$ glucose alonc.

The increase in insulin release at $5 \mathrm{mmol} / 1 \mathrm{glu}$ cose elicited by DAMME $\left(8.3 \times 10^{-8} \mathrm{~mol} / \mathrm{l}\right)$ was blocked by naloxone $1.1 \times 10^{-5} \mathrm{~mol} / \mathrm{l}$ (Table 2 ). In the absence of DAMME, naloxone did not affect insulin release. When insulin release in response to 
Table 2. Effects of naloxone, trifluoperazine and DAMME on glucosc-stimulated insulin release

\begin{tabular}{|c|c|c|c|c|c|c|c|}
\hline \multirow[t]{2}{*}{ Line } & \multicolumn{3}{|c|}{ Incubation conditions } & \multirow[b]{2}{*}{$\begin{array}{l}\text { Trifluoperazine } \\
\left(2 \times 10^{-5} \mathrm{~mol} / \mathrm{l}\right)\end{array}$} & \multirow[b]{2}{*}{$\begin{array}{l}\text { Insulin release } \\
(\mu \mathrm{U} / \mathrm{islet} / \mathrm{h})\end{array}$} & \multirow[b]{2}{*}{$\mathrm{n}$} & \multirow[b]{2}{*}{$\mathbf{p}$} \\
\hline & $\begin{array}{l}\text { Glucose concn. } \\
(\mathrm{mmol} / \mathrm{l})\end{array}$ & $\begin{array}{l}\text { DAMME } \\
\left(8.3 \times 10^{-8} \mathrm{~mol} / \mathrm{l}\right)\end{array}$ & $\begin{array}{l}\text { Naloxone } \\
\left(1.1 \times 10^{-5} \mathrm{~mol} / \mathrm{l}\right)\end{array}$ & & & & \\
\hline 1 & 5 & - & - & - & $39 \pm 8$ & 10 & \\
\hline 2 & 5 & - & + & - & $46 \pm 8$ & 10 & NS vs. 1 \\
\hline 3 & 5 & + & - & - & $87 \pm 11$ & 10 & $\leqslant 0.01$ vs. 1 \\
\hline 4 & 5 & + & + & - & $36 \pm 6$ & 10 & $\left\{\begin{array}{c}\text { NS vs. } 1 \\
\leqslant 0.001 \text {. } 3\end{array}\right.$ \\
\hline 5 & 7 & - & - & - & $105 \pm 9$ & 15 & \\
\hline 6 & 7 & + & - & - & $182 \pm 15$ & 15 & $\leqslant 0.001$ vs. 5 \\
\hline 7 & 7 & - & - & + & $64 \pm 13$ & 15 & $\leqslant 0.05$ vs. 5 \\
\hline 8 & 7 & + & - & + & $74=17$ & 15 & $\left\{\begin{array}{c}\leqslant 0.001 \text { vs. } 6 \\
\text { NS vs. } 7\end{array}\right.$ \\
\hline
\end{tabular}

Experimental details were as for Table 1. The numbers of separate islet preparations and rats used for the two experimental series were as follows: lines $1-4,4$ preparations, 8 rats; lines $5-8,3$ preparations, 6 rats

glucose $(7 \mathrm{mmol} / \mathrm{l})$ was inhibited by trifluoperazine $\left(2 \times 10^{-5} \mathrm{~mol} / \mathrm{l}\right)$, DAMME had no stimulatory effect (Table 2).

In one series of experiments, islets were cultured for 3 days in the presence or absence of DAMME $\left(8.3 \times 10^{-8} \mathrm{~mol} / \mathrm{l}\right)$. Insulin release in response to glucose, $\alpha$-ketoisocaproate and glibenclamide was then measured for both groups in the absence of DAMME. The secretory responses to glucose $(5 \mathrm{mmol} / \mathrm{l})$ and $\alpha$-ketoisocaproate $(7.5 \mathrm{mmol} / \mathrm{l})$ were unaffected by prior culture of the islets with DAMME whereas the response to glibenclamide was lower in the islets that had been cultured with DAMME than in the control islets $(113 \pm 6$ vs. $166 \pm 18 \mu \mathrm{U} /$ islet/h: $\mathrm{n}=15, \mathrm{p} \leqslant 0.05)$.

\section{Discussion}

The pentapeptide enkephalin (Tyr-Gly-Gly-PheMet) forms part of the sequence of the larger peptide B-endorphin which itself constitutes the last 31 residues of $B$-lipotrophin [23]. Since natural metenkephalin is quickly inactivated, the present studies have been carried out with the more stable analogue DAMME (Sandoz FK33-824). Significant effects of this analogue were found on insulin relcase with concentrations ranging from $1.7-8.3 \times 10^{-18} \mathrm{~mol} / 1$ $(10-50 \mathrm{ng} / \mathrm{ml})$. With glucose as the stimulus, the effect of DAMME was to increase the insulin released in response to glucose concentrations above the threshold but below maximally stimulating concentrations. This response to DAMME was blocked by the opiate antagonist naloxone, suggesting that it is mediated by specific opiate receptors. The fact that naloxone alone did not affect insulin release in the presence of $5 \mathrm{mmol} / \mathrm{l}$ glucose argues against effects of endogenous opiates persisting in the isolated islets but does not exclude a role for such activity in vivo. The possibility that locally secreted enkephalin may modulate insulin release in vivo is supported by the demonstration of enkephalin-like immunofluorescence in islet cells [12].

Both $\alpha$-ketoisocaproate and glibenclamide stimulate insulin release by mechanisms distinct from the $\beta$-cell glucoreceptor. Hence the fact that DAMME also potentiated insulin release in the presence of these agents suggests that the effect involves modification of a fundamental step in the release process itself, common to these agents and glucose, rather than being exerted on signal recognitition. The effect of DAMME appears to be dependent on the normal function of $\mathrm{Ca}^{2+}$ as a trigger for exocytosis; it was blocked by trifluoperazine which is suggested to interfere with insulin release by inhibiting the interaction of $\mathrm{Ca}^{2}$ with the calcium receptor protein calmodulin [24].

Other reports of effects of opiates on insulin release have been published. Thus enhancement of insulin relcase from perfused dog pancreas by B-endorphin $\left(5.4 \times 10^{-8} \mathrm{~mol} / \mathrm{l}\right)$ and morphine $\left(2 \times 10^{-6} \mathrm{~mol} / \mathrm{l}\right)$ in the presence of glucose $(5.5 \mathrm{mmol} / \mathrm{l})$ plus arginine $(10 \mathrm{mmol} / \mathrm{l})$ has been reported [15]: however these authors did not state whether the response to glucose alone was also modified. On the other hand, using neonatal rat pancreatic monolayer cultures, although morphine $\left(2 \times 10^{-5} \mathrm{~mol} / \mathrm{l}\right)$ enhanced insulin release in the presence of glucose $(5.5 \mathrm{mmol} / \mathrm{l})$ plus arginine $(10 \mathrm{mmol} / \mathrm{l})$, enkephalin $\left(1.2 \times 10^{-6} \mathrm{~mol} / \mathrm{l}\right)$ inhibited insulin release under the same conditions [16]. In the same study, the insulin secretory response to 
$16.7 \mathrm{mmol} / \mathrm{l}$ glucose was progressively inhibited by leucine-enkephalin, by methionine-enkephalin and by $\mathrm{D}$-ala ${ }^{2}$-leucine-enkephalin over the concentration range $2 \times 10^{-8}$ to $2 \times 10^{-6} \mathrm{~mol} / \mathrm{l}$. These inhibitory actions of enkephalins are apparently at variance with the results of the present study in which stimulation of insulin release by an enkephalin was observed. However, there are many methodological differences between the two studies including 1) the use in [16] of a pancreatic monolayer culture instead of adult rat islets; 2) measurements of insulin release were performed in culture medium containing amino-acids and calf serum in [16] but in a simple bicarbonate-buffered medium in our study; 3 ) the use here of a different enkephalin analogue from those used in [16]. In agreement with our findings, an enhancing effect of DAMME on glucose-stimulated insulin release was reported, while this manuscript was in preparation, by Green et al. [17] who showed that DAMME $\left(10^{-10}\right.$ to $\left.10^{-8} \mathrm{~mol} / \mathrm{l}\right)$ enhanced insulin release from rat islets stimulated by glucose $(8 \mathrm{mmol} / \mathrm{l})$; the effect was blocked by naloxone. The response to DAMME $\left(1.6 \times 10^{-8} \mathrm{~mol} / \mathrm{l}\right)$ was shown in perifusion experiments to be rapid and monophasic.

Since B-endorphin decreased somatostatin release from perfused dog pancreas [15], it was suggested that the action of $\mathrm{B}$-endorphin on insulin release was mediated by a primary action on the somatostatin-secreting D-cells. Such a mechanism could underlie the effect of DAMME reported here. Localisation of enkephalin receptors to particular islet cell types could provide further insight.

The observation of a stimulatory effect of DAMME on glucose-stimulated insulin release was critically dependent on both glucose and DAMME concentrations: at a high concentration of DAMME $\left(3.3 \times 10^{-6} \mathrm{~mol} / \mathrm{l}\right)$ no effect on insulin release was observed. This observation is consistent with the data of Green et al. [17] who found that $10^{-6} \mathrm{~mol} / \mathrm{l}$ DAMME did not stimulate insulin release in the presence of $8 \mathrm{mmol} / 1$ glucose; $10^{-5} \mathrm{~mol} / \mathrm{l}$ DAMME inhibited glucose-stimulated insulin release. This may underlie the failure to detect changes in insulin release in normal man given intravenous DAMME [18] or naloxone [11], although equally the concurrent changes in blood levels of many hormones and metabolites may have obscured any effect on insulin.

The stimulatory effect of DAMME was observed in short-term incubations of islets. The secretory behaviour of such islets has been found to be profoundly influenced by the presence in the culture medium of hormones including growth hormone [25] and glucocorticoids (unpublished observations) during the culture period. It was therefore of interest to assess the effect of long-term treatment of the islets during a 3-day culture period with DAMME. However the insulin secretory responses were not enhanced by this treatment and, indeed, the response to glibenclamide was somewhat impaired.

The present studies thus confirm that insulin secretion is capable of being acutely modified by opioid peptides, although the mechanisms involved remain unknown, and provide some support for the hypothesis that an altered sensitivity to opioid peptides may be causally related to the development of non-insulin dependent diabetes [5,6]. Direct evidence for this hypothesis is still lacking.

Acknowledgements. These studies were supported by grants from the Medical Research Council, the British Diabetic Association and the British Insulin Manufacturers.

\section{References}

1. Tattersall RB, Pyke DA (1972) Diabetes in identical twins. Lancet II: $1120-1125$

2. Pyke DA, Nelson PG (1976) Diabetes mellitus in identical twins. In: Creutzfeldt W, Kobberling J, Neel JV (eds) The genetics of diabetes mellitus. Springer, Berlin Heidelberg New York, p 194-202

3. Nelson PG, Pyke DA, Cudworth AG, Woodrow JC, Batchelor JR (1975) Histocompatibility antigens in diabetic identical twins. Lancet II: 193-194

4. Leslie RDG, Pyke DA (1978) Chlorpropamide alcohol flushing: a dominantly inherited trait associated with diabetes. $\mathrm{Br}$ Med J II: 1519-1521

5. Leslie RDG, Pyke DA, Stubbs WA (1979) Sensitivity to enkephalin as a cause of non-insulin dependent diabetes. Lancet I: $341-343$

6. Pyke DA (1979) Diabetes: the genetic connections. Diabetologia 17: 333-343

7. Cudworth AG (1979) Type 2 (insulin-dependent) diabetesfibres and flushers. Diabetologia 17: 67-69

8. Dupont A, Cusan L, Labrie F, Coy DM, Li CH (1977) Stimulation of prolactin release in the rat by intraventricular injection of $\beta$-endorphin and methionine-enkephalin. Biochem Biophys Res Commun 15: 76-82

9. Lien EL, Clark DE, McGregor NH (1978) Stimulation of growth hormone and prolactin release by a potent enkephalin analogue. FEBS Lett 88: 208-210

10. Neitzman RE, Fisher DA, Minick $S$, Ling N, Guillemin $R$ (1977) $\beta$-Endorphin stimulates secretion of arginine-vasopressin in vivo. Endocrinology 101: 1643-1646

11. Morley JE, Baranetsky NG, Wingert TD, Carlson HE, Hershman JM, Melmed S, Levin SR, Jamison KR, Weitzman R, Chang RJ, Varner AA (1980) Endocrine effects of naloxoneinduced opiate receptor blockade. J Clin Endocrinol Metab 50: $251-257$

12. Forsmann WG, Helmstaedter V, Feurle G (1977) Relationship of enkephalin and endorphin immunoreactivity with $D$ cells and G-cells of stomach. Acta Hepatogastroenterol (Stuttg) 24: 488-491

13. Grube D, Voight KH, Weber E (1978) Pancreatic glucagon cells contain endorphin-like immunoreactivity. Histochemistry 59: $75-79$ 
14. Bruni JF, Watkins WB, Yen SSC (1979) $\beta$-Endorphin in the human pancreas. J Clin Endocrinol Metab 49: 649-651

15. Ipp E, Dobbs R, Unger RM (1978) Morphine and $\beta-$-endorphin influence the secretion of the endocrine pancreas. Nature 276: $190-191$

16. Kanter RA, Ensinck JW, Fujimoto WY (1979) Disparate effects of enkephalin and morphine upon insulin and glucagon secretion by islet cell cultures. Diabctes 29: 84-86

17. Green IC, Perrin D, Pcdley KC, Leslic RDG, Pyke DA (1980) Effect of enkephalins and morphine on insulin secretion from isolated rat islets. Diabetologia 19: 158-161

18. Stubbs WA, Delitala G, Jones A, Jeffcoate WJ, Edwards CRW, Ratter SJ, Besser GM, Bloom SR, Alberti KGMM (1978) Hormonal and metabolic responses to an enkephalin analogue in normal man. I ancet II: 1225-1227

19. Coll-Garcia E, Gill JR (1969) Insulin release by isolated islets of the mouse incubated in vitro. Diabetologia 5: 61-66

20. Krebs HA, Henselcit K (1932) Untersuchungen über dic Harnstoffbildung im Ticrkörper. Hoppe-Seylers Z Physiol Chem 210: 33-62

21. Asheroft SJH, Crossley JR (1975) The effects of glucose, Nacetylglucosamine, glyceraldehyde and other sugars on insulin release in vivo. Diabetologia 11:279-284
22. Von Fraunhofer JA, Murray JJ (1976) Statistics in medical dental and biological studies. Tri-med, London

23. Bradbury AF, Smith DG, Snell CR (1976) Lipotrophin: precursor to two biologically active peptides. Biochem Biophys Res Commun 69: 950-956

24. Sugden MC, Ashcroft SJH (1979) Presence and possible role of calcium-dependent regulator (calmodulin) in rat islets of Langerhans. FEBS Lett 105: 95-100

25. Pierluissi J, Pierluissi R, Asheroft SJH (1980) Effects of growth hormone on insulin release in the rat. Diabetologia 19: 391-396

Received: 16 July 1980

and in revised form: 23 October 1980

Dr. S. J. H. Ashcroft

Nuffield Department of Clinical Biochemistry

John Radcliffe Hospital

Headington

Oxford OX3 9DU

England 